\title{
Preclinical evaluation of nephroprotective potential of a probiotic formulation LOBUN on Cyclosporine-A induced renal dysfunction in Wistar rats
}

\author{
Kambham Venkateswarlu ${ }^{*}$, Thakur Heerasingh², Chilamakuru Naresh Babu ${ }^{3}$, \\ Singirisetty Triveni ${ }^{3}$, Suroju Manasa ${ }^{4}$, Thumati Nagendra Bhaskar Babu ${ }^{5}$
}

\begin{abstract}
${ }^{1}$ Department of Pharmaceutics, JNTUA Oil Technological and Pharmaceutical Research Institute, Ananthapuramu, A.P., India, ${ }^{2}$ Drug Safety Scientist, Cognizant Technology Solutions, Hyderabad,Telangana, India, ${ }^{3}$ Department of Pharmaceutical Chemistry, Raghavendra Institute of Pharmaceutical Education and Research, Ananthapuramu, A.P., India, ${ }^{4}$ Department of Pharmaceutics, Vikas College of Pharmacy, Telangana, India, ${ }^{5}$ QA Executive, FR\&D, Aurobindo Pharma Ltd (Unit-III), Hyderabad, Telangana, India
\end{abstract}

\begin{abstract}
The aim of present study was to evaluate the nephroprotective effect of probiotic formulation LOBUN on Cyclosporine A (CsA) induced renal dysfunction in Wistar rats. CsA (20 mg/kg body weight s.c) was administered for 15 days to cause renal dysfunction in Wistar rats. The probiotic formulation LOBUN was administered with the dose of $500 \mathrm{mg} / \mathrm{kg}$ body weight (p.o) for twice (TGI) and thrice a day (TGII). The samples were analyzed for the parameters like blood urine nitrogen (BUN), serum creatinine, serum uric acid, total serum protein and urine proteins, urine potassium, urine sodium. The renal functional and histopathological studies revealed that the oral administration of probiotic formulation LOBUN has provided appreciable renoprotection and possibly alleviated the symptoms of Chronic Kidney Disease (CKD) at the dose of $500 \mathrm{mg} / \mathrm{kg}$ body weight administered thrice a day and also the results were supported by histopathological findings.
\end{abstract}

Uniterms: Cyclosporine-A. LOBUN/effects. LOBUN/effects/evaluation. Nephroprotective activity. Prebiotics. Probiotics. Chronic Kidney Disease/study.

\section{INTRODUCTION}

Chronic Kidney Disease (CKD) is a potentially fatal health problem with an ever-increasing incidence and prevalence particularly in the under developed and developing countries whose health infrastructure is unable to meet the therapeutic needs of large section of population who are economically deprived to afford the high cost of dialysis and renal transplantation. CKD in most cases is largely under or misdiagnosed, followed by under treatment leading to poor clinical outcome and development of irreversible cardiovascular complications and end stage of renal disease (Andrew, Coresh, 2012). Research and development of appropriate therapeutics

\footnotetext{
*Correspondence: $\mathrm{K}$. Venkateswarlu. Department of Pharmaceutics. JNTUAOil Technological and Pharmaceutical Research Institute. Ananthapuramu-515001 - Andhra Pradesh, India. E-mail: k.v.reddy9441701016@gmail.com; k.v.pharmacy@jntua.ac.in
}

based on pathophysiological cascade can be envisaged to retard the progression of CKD and improve the quality of life in patients with compromised renal function.

Cyclosporine A (CsA) is a calcineurin inhibitor which has remained for many years as a crucial immunosuppressant drug with major therapeutic role in early kidney transplantation in various autoimmune diseases (Maria, Perego, Bellia, 2013). However, these therapeutic benefits have been unfortunately limited by the most serious complications like nephrotoxicity and cardiovascular events. CsA nephrotoxicity is associated with imbalanced red-ox state and associated oxidative stress in renal tubular, endothelial and glomerular cells. It is accomplished by the development of morphological changes including vascular injury with ischemic damage, afferent arteriolopathy, intestinal fibrosis, progressive glomerular sclerosis, tubular and renal cell apoptosis (Subha Palaneeswar, Nagarajan, Manjula Devi, 2014; Jinhwa, 2010). 
Hence, in the present study, we have selected CsA as nephrotoxic agent to induce renal dysfunction in Wistar rats as this model closely mimics the renal pathological events of humans in various aspects. The selection of probiotic formulation was based on the fact that oral administration of beneficial microbes may metabolize nitrogenous wastes that generally accumulate during renal dysfunction leading to azotemia and may serve as a potential dietary supplement (Koppe, Mafra, Fouque, 2015). We had employed a probiotic formulation LOBUN consisting of a mixture of specific strains of beneficial microorganisms viz. Streptococcus thermophilus, Lactobacillus acidophilus, Bifidobacterium longum, Lactic acid bacillus (Lactobacillus sporogenes) and a prebiotic compound viz. Fructooligosaccharides (FOS) to evaluate its renoprotective potential.

\section{MATERIAL AND METHODS}

\section{Experimental animals}

Adult, healthy, male Wistar rats weighing between 150-200 g, maintained under controlled conditions of temperature $\left(25 \pm 2{ }^{\circ} \mathrm{C}\right)$ and relative humidity $(50-70 \%$ $\mathrm{RH})$ were selected for this study. The rats were allowed standard pelleted chow and tap water ad libitum with $12 \mathrm{~h}$ duration of light and dark cycle. They were acclimatized to the laboratory conditions for a week and then randomly divided into four experimental groups of five animals each (Pradeep, Narasimha, 2014). All the experimental procedures were carried out in accordance with the Committee for the Purpose of Control and Supervision of Experiments on Animals (CPCSEA) guidelines (Reg. No. 168/PO/e/13/CPCSEA), Government of India.

\section{Composition of probiotic formulation LOBUN}

Each delayed release vegetable capsule of "LOBUN" has contained the following probiotics in a concentration of not less than 15 billion CFUs taken together. The probiotic organisms include Streptomyces thermophilus, Lactobacillus acidophilus, Bifidobacterium longum, Lactic acid bacillus (Lactobacillus sporogenes) and a prebiotic compound viz. FOS (100 mg).

\section{Drugs and chemicals}

Anesthetic ether (Kabra Drugs Ltd., India), CsA (Apollo Pharmaceuticals, Hyderabad), Ethanol (Changshu Yangyum Chemicals, China), Formalin (SD-Fine Chem Pvt. Ltd., India) and diagnostic kits for blood urea nitrogen
(BUN), serum creatinine, serum uric acid, serum total protein, urinary sodium, urinary potassium, urinary protein estimation were purchased from Span Diagnostics Ltd., India.

\section{Acute oral toxicity study of the probiotic formulation LOBUN in Wistar rats}

The study was performed using Wistar rats as per Organization for Economic Co-operation and Development (OECD) Guidelines No. 420 (Section 4: Health effects). The probiotic formulation LOBUN was found to be nontoxic and safe up to $5000 \mathrm{mg} / \mathrm{kg}$ body weight by oral route. It was found that the none of the doses produced any signs of toxicity and the animals were survived for a period of 14 days. Hence, $1 / 10^{\text {th }}$ of the maximum dose i.e. $500 \mathrm{mg} / \mathrm{kg}$ body weight was selected as test dose for the present study.

\section{Experimental design}

The experimental animals were randomly divided into 4 groups of 5 rats each and were kept on treatment schedule as follows.

I. Normal group animals received the vehicle of CsA alone i.e. Olive oil along with regular feed and water. This group mainly serves to study the normal renal physiology and histology.

II. Control group animals received CsA dissolved in olive oil at the dose of $20 \mathrm{mg} / \mathrm{kg}$ body weight (s.c) once daily for 15 days to induce nephrotoxicity and this group serves to study the renal pathology under the influence of nephrotoxic drug.

III. Therapeutic group-I (TGI) rats were treated with CsA (20 mg/kg body weight, s.c) for 15 days followed by the administration of probiotic formulation LOBUN at the dose of $500 \mathrm{mg} / \mathrm{kg}$ body weight (p.o) twice a day from $15^{\text {th }}$ day onwards to $28^{\text {th }}$ day.

IV. Therapeutic group-II (TGII) rats were treated with CsA (20 mg/kg body weight, s.c) for 15 days followed by the administration of probiotic formulation LOBUN at the dose of $500 \mathrm{mg} / \mathrm{kg}$ body weight (p.o) thrice a day from $15^{\text {th }}$ day onwards to $28^{\text {th }}$ day.

\section{Blood sample collection and analysis}

The blood samples were withdrawn periodically from the retro orbital venous plexus of rats under ether anesthesia using glass capillary tube and the collected blood was centrifuged (2,500 rpm for $10 \mathrm{~min}$ ) to obtain clear serum sample. The serum was subjected for 
subsequent biochemical estimations of BUN, creatinine, uric acid and plasma proteins (Parasuraman, Raveendran, Kesavan, 2010).

\section{Urine sample collection and analysis}

Urine samples were collected periodically by placing the animals in metabolic cages. Animals had free access to drinking water during this collection period (i.e. $4 \mathrm{~h}$ ) and samples were subjected to analysis of sodium, potassium, urinary protein content by using standard method of estimation (Patel et al.,2012).

\section{Body weight}

Body weight of experimental animals under study was measured periodically at 0,14 and $28^{\text {th }}$ day of study period and assessed to evaluate therapeutic effect of the probiotic formulation LOBUN on body weight of the rats.

\section{Histopathological study}

Animals were sacrificed and the kidneys of each animal were isolated. The isolated kidneys were preserved and fixed in $10 \%$ formalin for 2 days. Following this was the washing step where by the kidney pieces were washed in running water for about $12 \mathrm{~h}$. This was followed by dehydration with isopropyl alcohol of increasing strength $(70 \%, 80 \%$ and $90 \%)$ for $12 \mathrm{~h}$ each. Then the final dehydration was done using absolute alcohol with about 3 changes for $12 \mathrm{~h}$. The clearing was done by chloroform with 2 changes for 15 to $20 \mathrm{~min}$ each. After clearing, the kidney pieces were subjected to paraffin infiltration in automatic tissue processing unit. The kidney pieces were then dropped into the L-shaped blocks containing molten paraffin quickly and allow cooling. The blocks were sectioned by using microtome to get the thickness of sections about $5 \mu$. The sections were taken on a micro slide and covered by egg albumin (sticking substance).
Then the sections were allowed to remain in an oven at $60^{\circ} \mathrm{C}$ for $1 \mathrm{~h}$, paraffin melts and egg albumin denaturates, thereby fixes tissues to the slide. Sections were stained by using eosin (acid stain) and haematoxylin (basic stain). All the tissue sections were examined using microscope for analyzing the altered architecture of tissue under the different components of treatment schedule (Hodgkinson, 1970).

\section{Statistical analysis}

All the data was expressed as mean \pm SEM. Statistical significance between different groups was tested by two-way ANOVA followed by Tukey's multiple comparisons test using computer based fitting program (GraphPad Prism Version 6.03) and statistical significance was set at $(\mathrm{P}<0.01)$.

\section{RESULTS}

After treatment with probiotic formulation LOBUN, blood and urine samples were analyzed for the parameters like BUN, creatinine, uric acid, total serum protein (Table I-IV) and urinary protein, potassium, sodium (Table V-VII) respectively. Control group animals showed increase in concentration of the blood parameters such as BUN, creatinine, uric acid and reduced in case of total serum proteins when compared to the normal group animals, which indicates that the toxicity was induced in control group animals. After treatment with probiotic formulation LOBUN at the dose of $500 \mathrm{mg} / \mathrm{kg}$ body weight (twice a day (b.i.d) and thrice a day (t.i.d)), the TGs were showed significant reduction in concentrations of the parameters such as serum BUN, serum creatinine, serum uric acid and significant increase in total serum protein when compared to the control group. After induction of nephrotoxicity, urine parameters like urine protein concentration was increased and potassium, sodium concentrations were reduced in urine sample of control group when compared to the normal group animals. After

TABLE I - Effect of the probiotic formulation LOBUN on blood urea nitrogen levels in nephrotoxic Wistar rats

\begin{tabular}{lcccc}
\hline \multirow{2}{*}{ Group } & \multicolumn{4}{c}{ Blood urea nitrogen $\mathbf{( m g / d L )}$} \\
\cline { 2 - 5 } & $\mathbf{0}^{\text {th }} \mathbf{d a y}$ & $\mathbf{7}^{\text {th }}$ day & $\mathbf{1 4}^{\text {th }}$ day & $\mathbf{2 8}^{\text {th }}$ day \\
\hline Normal & $9.6 \pm 0.244$ & $9.8 \pm 0.489^{* * * *}$ & $10 \pm 0.316^{* * * *}$ & $10.20 \pm 0.374^{* * * *}$ \\
Control & $11.6 \pm 0.509$ & $26 \pm 1.048$ & $34.8 \pm 1.46$ & $41.60 \pm 1.630$ \\
TGI & $10.6 \pm 0.60$ & $25.6 \pm 1.288$ & $34.6 \pm 1.913$ & $14.94 \pm 1.075^{* * * *}$ \\
TGII & $10.8 \pm 0.374$ & $24.8 \pm 1.157$ & $34 \pm 1.303$ & $11.92 \pm 0.68^{* * * * *}$ \\
\hline
\end{tabular}

Note: All the values of mean \pm SEM $(\mathrm{n}=5)$. Significant fromcontrol $* * * * \mathrm{P}<0.0001$. 
TABLE II - Effect of the probiotic formulation LOBUN on serum creatinine levels in nephrotoxic Wistar rats

\begin{tabular}{lcccc}
\hline \multirow{2}{*}{ Group } & \multicolumn{4}{c}{ Serum creatinine $\mathbf{( m g / d L )}$} \\
\cline { 2 - 5 } & $\mathbf{0}^{\text {th }} \mathbf{d a y}$ & $\mathbf{7}^{\text {th }}$ day & $\mathbf{1 4}^{\text {th }}$ day & $\mathbf{2 8}^{\text {th }}$ day \\
\hline Normal & $0.60 \pm 0.09^{\text {ns }}$ & $0.62 \pm 0.066^{* * * *}$ & $0.64 \pm 0.05^{* * * *}$ & $0.60 \pm 0.031^{* * * *}$ \\
Control & $0.8 \pm 0.044$ & $3.32 \pm 0.152$ & $4.44 \pm 0.102$ & $6.32 \pm 0.217$ \\
TGI & $0.84 \pm 0.05$ & $3.34 \pm 0.143$ & $4.46 \pm 0.05$ & $3.60 \pm 0.151^{* * * *}$ \\
TGII & $0.86 \pm 0.05$ & $3.30 \pm 0.118$ & $4.46 \pm 0.067$ & $1.82 \pm 0.086^{* * * * *}$ \\
\hline
\end{tabular}

Note: All the values of mean \pm SEM $(\mathrm{n}=5)$. Significant from control $* * * * \mathrm{P}<0.0001$.

TABLE III - Effect of the probiotic formulation LOBUN on serum uric acid levels in nephrotoxic Wistar rats

\begin{tabular}{lcccc}
\hline \multirow{2}{*}{ Group } & \multicolumn{4}{c}{ Serum uric acid $\mathbf{( m g / d L )}$} \\
\cline { 2 - 5 } & $\mathbf{0}^{\text {th }} \mathbf{d a y}$ & $\mathbf{7}^{\text {th }}$ day & $\mathbf{1 4}^{\text {th }}$ day & $\mathbf{2 8}^{\text {th }}$ day \\
\hline Normal & $2.080 \pm 0.146$ & $2.140 \pm 0.136^{* * * *}$ & $2.140 \pm 0.068^{* * * *}$ & $2.000 \pm 0.089^{* * * *}$ \\
Control & $2.200 \pm 0.114$ & $4.960 \pm 0.194$ & $7.460 \pm 0.447$ & $7.540 \pm 0.333$ \\
TGI & $2.160 \pm 0.075$ & $4.520 \pm 0.213$ & $7.360 \pm 0.317$ & $5.540 \pm 0.169^{* * * *}$ \\
TGII & $2.140 \pm 0.178$ & $4.340 \pm 0.163$ & $7.600 \pm 0.270$ & $3.160 \pm 0.194^{* * * *}$ \\
\hline
\end{tabular}

Note: All the values of mean \pm SEM $(\mathrm{n}=5)$. Significant from control $* * * * \mathrm{P}<0.0001$.

TABLE IV - Effect of the probiotic formulation LOBUN on total serum protein levels in nephrotoxic Wistar rats

\begin{tabular}{lcccc}
\hline \multirow{2}{*}{ Group } & \multicolumn{4}{c}{ Total serum protein $(\mathbf{g} / \mathbf{d L})$} \\
\cline { 2 - 5 } & $\mathbf{0}^{\text {th }} \mathbf{d a y}$ & $\mathbf{7}^{\text {th }} \mathbf{d a y}$ & $\mathbf{1 4}^{\text {th }} \mathbf{d a y}$ & $\mathbf{2 8}^{\text {th }}$ day \\
\hline Normal & $6.56 \pm 0.154$ & $6.92 \pm 0.136^{* * * *}$ & $6.88 \pm 0.128^{* * * *}$ & $6.90 \pm 0.164^{* * * *}$ \\
Control & $6.80 \pm 0.161$ & $4.24 \pm 0.103$ & $2.96 \pm 0.121$ & $2.14 \pm 0.050$ \\
TGI & $6.90 \pm 0.105$ & $4.12 \pm 0.116$ & $3.10 \pm 0.017$ & $5.44 \pm 0.150^{* * * *}$ \\
TGII & $6.74 \pm 0.181$ & $4.28 \pm 0.159$ & $3.160 \pm 0.0093$ & $6.38 \pm 0.115^{* * * *}$ \\
\hline
\end{tabular}

Note: All the values of mean \pm SEM $(\mathrm{n}=5)$. Significant from control $* * * * \mathrm{P}<0.0001$.

TABLE V - Effect of the probiotic formulation LOBUN on urinary protein levels in nephrotoxic Wistar rats

\begin{tabular}{lcccc}
\hline \multirow{2}{*}{ Group } & \multicolumn{4}{c}{ Urinary protein $(\mathbf{g} / \mathbf{d L})$} \\
\cline { 2 - 4 } & $\mathbf{0}^{\text {th }} \mathbf{d a y}$ & $\mathbf{7}^{\text {th }}$ day & $\mathbf{1 4}^{\text {th }}$ day & $\mathbf{2 8}^{\text {th }} \mathbf{d a y}$ \\
\hline Normal & $6.12 \pm 0.128$ & $6.2 \pm 0.202^{* * *}$ & $6.28 \pm 0.177^{* * * *}$ & $6.26 \pm 0.13^{* * * *}$ \\
Control & $6.18 \pm 0.048$ & $7.86 \pm 0.156$ & $9.38 \pm 0.174$ & $11.88 \pm 0.941$ \\
TGI & $6 \pm 0.083$ & $7.92 \pm 0.168$ & $9.32 \pm 0.278$ & $7.42 \pm 0.156^{* * * *}$ \\
TGII & $6 \pm 0.086$ & $8.02 \pm 0.182$ & $9.36 \pm 0.180$ & $6.70 \pm 0.091^{* * * *}$ \\
\hline
\end{tabular}

Note: All the values of mean \pm SEM $(\mathrm{n}=5)$. Significant from control $* * * * \mathrm{P}<0.0001$.

treatment, the TGs showed significant reduction in urine protein concentration and sodium, potassium levels were significantly increased in urine. TG animals were exhibited significant increase in body weight than control group animals (Table VIII).

\section{Effect of probiotic formulation LOBUN on renal histology in nephrotoxic Wistar rats}

The kidney section of normal group animals showed normal renal architecture i.e. normal glomerular 
Preclinical evaluation of nephroprotective potential of a probiotic formulation LOBUN on Cyclosporine-A induced renal dysfunction in Wistar rats

TABLE VI - Effect of the probiotic formulation LOBUN on urinary potassium levels in nephrotoxic Wistar rats

\begin{tabular}{lcc}
\hline \multirow{2}{*}{ Group } & \multicolumn{2}{c}{ Urinary potassium $(\mathbf{m e q} / \mathbf{L})$} \\
\cline { 2 - 3 } & $\mathbf{0}^{\text {th }}$ day & $\mathbf{2 8}^{\text {th }}$ day \\
\hline Normal & $7.44 \pm 0.453$ & $7.02 \pm 0.363^{* * *}$ \\
Control & $6.56 \pm 0.10$ & $4.88 \pm 0.048$ \\
TGI & $7.32 \pm 0.312$ & $6.44 \pm 0.156^{* *}$ \\
TGII & $7.18 \pm 0.31$ & $6.62 \pm 0.04^{* *}$ \\
\hline
\end{tabular}

Note: All the values of mean \pm SEM $(n=5)$. Significant from control $* * * \mathrm{P}<0.001,{ }^{* *} \mathrm{p}<0.01$.
TABLE VII - Effect of the probiotic formulation LOBUN on urinary sodium levels in nephrotoxic Wistar rats

\begin{tabular}{lcc}
\hline \multirow{2}{*}{ Group } & \multicolumn{2}{c}{ Urinary sodium $(\mathbf{m e q} / \mathbf{L})$} \\
\cline { 2 - 3 } & $\mathbf{0}^{\text {th }}$ day & $\mathbf{2 8}^{\text {th }}$ day \\
\hline Normal & $150 \pm 5.319$ & $151 \pm 4.571^{* * *}$ \\
Control & $142.2 \pm 3.337$ & $93.4 \pm 069$ \\
TGI & $149.2 \pm 5.388$ & $140.4 \pm 3.075^{* *}$ \\
TGII & $155.2 \pm 4.004$ & $146.6 \pm 2.675^{* * *}$ \\
\hline
\end{tabular}

Note: All the values of mean $\pm \operatorname{SEM}(\mathrm{n}=5)$. Significantfromcontrol $* * * \mathrm{P}<0.001, * * \mathrm{p}<0.01$.

TABLE VIII - Effect of the probiotic formulation LOBUN on body weight in nephrotoxic Wistar rats

\begin{tabular}{lccc}
\hline \multirow{2}{*}{ Group } & \multicolumn{3}{c}{ Body weight $(\mathrm{g})$} \\
\cline { 2 - 4 } & $0^{\text {th }}$ day & $14^{\text {th }}$ day & $28^{\text {th }}$ day \\
\hline Normal & $124.8 \pm 0.860$ & $145.33 \pm 1.101^{* * * *}$ & $163.274 \pm 0.952^{* * * * *}$ \\
Control & $122.4 \pm 0.927$ & $105.20 \pm 0.860$ & $102.14 \pm 0.727$ \\
TGI & $124.9 \pm 0.707$ & $107.8 \pm 0.861$ & $122.21 \pm 0.688^{* * * *}$ \\
TGII & $122.9 \pm 0.842$ & $108.2 \pm 0.663$ & $121.98 \pm 0.956^{* * * *}$ \\
\hline
\end{tabular}

Note: All the values of mean \pm SEM $(\mathrm{n}=5)$. Significant from control $* * * * \mathrm{P}<0.0001$.

and normal renal interstitium (Figure 1A). The renal section of control group animal has showed tubular and glomerular injury with dilation of Bowman's capsule and infiltration of cells in the interstitium and a marked tubular necrosis was observed (Figure 1B). However, the photomicrography of TGI revealed mild necrosis with reduced inflammatory infiltration and vacuolization (Figure 1C). Further with TGII, the prominence of these renal damages was reduced indicates that the LOBUN at the dose of $500 \mathrm{mg} / \mathrm{kg}$ t.i.d. might be effective in reversing the tubular interstitial damage (Figure 1D).

\section{DISCUSSION}

BUN is a sensitive but not highly specific marker in CKD because BUN as such relatively non toxic and functions more as a marker for other low molecular weight uremic toxins (Zeba, Pandey, 2014; Shigehiko, Bellomo, Goldsmith, 2012). The significantly elevated BUN levels in control group compared to normal group indicates gross reduction in the number of functioning nephrons due to tubular necrosis.

Uremia is the prime contributing factor for the progression of CKD. Uremia can be defined as the accumulation of numerous nitrogenous molecules generated by microbial protein metabolism in the large intestine such as p-cresol, indole, phenyl acetic acid, cadaverine, putrescine etc. and in the blood as compromised renal function is unable to excrete them. In $\mathrm{CKD}$, it was established that increased amounts of protein escapes digestion and absorption in the small intestine leading to increased content of nitrogen in the colon. This increased nitrogen content aids in the development of proteolytic species of bacteria that predominately ferments the proteins and generates uremic toxins. Saccharolytic species are those bacteria that ferment carbohydrates (Flore, 2012). Presently drug therapy in uremia proved to be unsuccessful or to a large extent, has not been tested. Hence efforts to study the drug therapy targeted to colonic micro environment may be a fruitful approach. This can be achieved by modulating the bacterial growth in colon by increasing the concentration of saccharolytic and decreasing the concentration of proteolytic species leading to reduced generation of uremic toxins. In colon, the main source of energy for bacterial growth is carbohydrates (CHO). In excess $\mathrm{CHO}$ availability, the bacteria will utilize $\mathrm{CHO}$ for growth and replication. If the $\mathrm{CHO}$ is deprived, the bacteria depend exclusively upon the available proteins for their growth which leads to fermentation of proteins and generation of uremic toxins. Thus, modulation of ration of $\mathrm{CHO}$ to protein indirectly aids the growth of saccharolytic species 


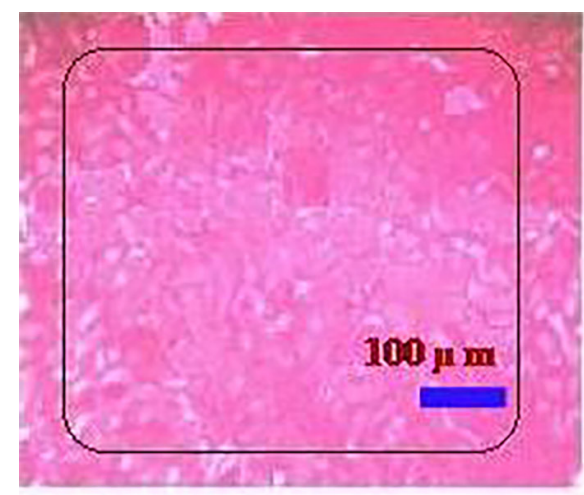

A. Normal group

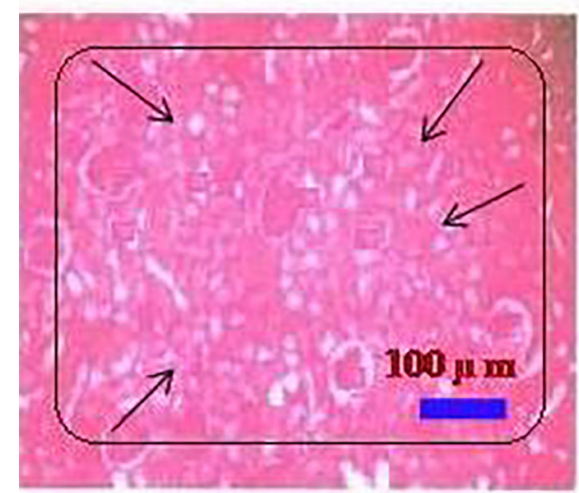

C. TGI

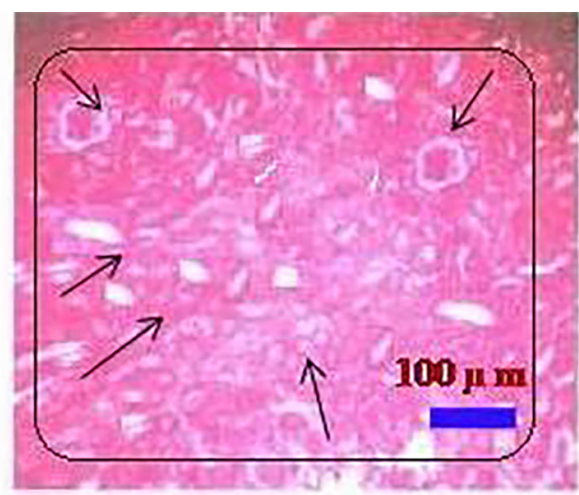

B. Control group

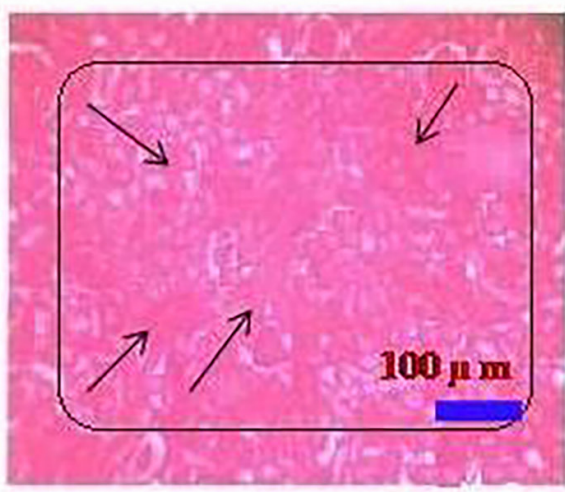

D. TGII

FIGURE 1 - Histopathology of kidney in various treatment groups.

(Hill, 1995). Hence, supplementation of saccharolytic species in this formulation might have reduced BUN levels in both the TGs and contributed to improved renal function. Here the prebiotic, FOS, beneficially affects the host by structurally stimulating the growth and/or activity of bacteria in the colon. FOS, a fermentable oligosaccharide also serves as a reservoir of $\mathrm{CHO}$, thus contributing to the reduced metabolism of proteins by bacteria and also generation of uremic toxins.

Serum creatinine is the breakdown product of creatinine phosphate in muscle and is usually produced at a fairly constant rate by the body depending on the muscle mass and is completely filtered out of blood by glomerular filtration and proximal tubular secretion. This is very little to know tubular reabsorption of creatinine. Serum creatinine levels were used to calculate creatinine clearance which regulates GFR, the gold standard for renal function (Zeba, Pandey, 2014). Drastic elevation of serum creatinine in control group is due to the renal failure and reflects massive reduction in the number of nephrons along with compromised function in surviving ones (Ramesh, 2014). Reduction of serum creatinine reveals good prognostic application of probiotic formulation LOBUN in both TGs.

Uric acid is formed by the breakdown of purines and by direct synthesis from 5-phosphoribosyl phosphate and glutamate. In kidneys, uric acid is filtered, reabsorbed and secreted (Christin et al., 2015). The elevated uric acid (hyperurecemia) level clearly signifies that the CsA has drastically reduced the renal function and these elevated levels of uric acid might have association with the CKD by several ways like a) It may exacerbate other risk factors for CKD like hypertension, b) Directly toxic to kidney, c) It might be a marker of severity for some other risk factors like those have association with diabetes and metabolic syndromes. It was observed from the animal studies that the mild elevation in uric acid (hyperuricemia) was toxic to the kidneys and also caused systemic hypertension. Finally, uric acid may be a marker of kidney risk factor than a direct contributor to the kidney injury (Ryu et al, 2013; Daniel, 2008). However, the reduction of serum uric acid levels in the TGs shows that the probiotic might have reduced the progression of CKD. The TGII was more significant in reducing serum uric acid than TGI. 
The reduced serum protein concentration in control group with reference to normal group indicates the hepatic dysfunction. This is because CKD is always accompanied by hepatorenal syndrome and thus compromising the synthetic ability of liver (Klammt et al., 2011). However, the improvement in serum protein levels in both the TGs indicates retardation of CKD progression and thereby improving hepatic function indirectly.

Under normal physiological conditions, very small amount of proteins get excreted and major component of this is albumin (Margaret, Gehr, 2011). Proteinuria of persistently elevated protein content in urine signifies altered permeability due to tubule interstitial disease in control group. Persistent proteinuria leads to decrease in plasma oncotic pressure and subsequent edema (Anwar et al., 2000). Thus, a decreased urinary protein in TGI and TGII indicates that the probiotic might have retarded the further progression of CKD.

The depression of urinary potassium levels in the control group with respect to normal signifies the disruption of potassium secretary mechanism leading to its retardation in the body (Emma et al., 2012); Shah, Kalantar-Zadeh, Kopple, 2015). However, the slight elevation in urinary potassium levels in TGI and TGII indicates stabilization of renal secretary mechanism with increased frequency of administration.

The reduction in urinary sodium excretion as evident in control group with respect to normal clearly indicates glomerulotubular damage leading to retention of excessive amounts of sodium. This can be related as proteinuria leads to decreased plasma oncotic pressure and movement of fluid from vasculature into interstitial spaces contributing to edema. Thus, the reduced plasma volume triggers an increase in aldosterone secretion via the rennin angiotensin in an effort to raise the blood pressure, sodium retention and related cardiovascular complication (Emma et al., 2012; Kovesdy, 2012). Thus the increase in the urinary sodium levels in TGII group compared to TGI indicates the improved glomerulotubular function.

The body weight in control group animals reduced significantly with respect to normal due to increased skeletal muscle breakdown and reduced lean body mass (Anwar et al., 2000). Further proteinuria might also have contributed to reduction in body weight of control group. However, the weight gain in TGI and TGII can be contributed to significant reduction of muscle protein breakdown and proteinuria.

Histopathological finding revealed that CsA administration has damaged renal architecture with vacuolization and images of TGI and TGII revealed significant reduction of tubule interstitial damage and moderate regeneration of renal tissues. This preclinical study has revealed that the oral ingestion of probiotic formulation LOBUN at a dose of $500 \mathrm{mg} / \mathrm{kg}$ body weight (t.i.d) has significant progression importance and this drug appear as a promising candidate to ameliorate CKD progression and further investigation in this aspect might have fruitful results in the development of nephroprotective agents from beneficial microorganisms.

\section{CONCLUSION}

Uremic retention molecules were generated by gut microbiota largely contributes to CKD progression as well its morbidity and the approach to reduce uremia is an attractive arena of research. In this regard, the present preclinical study evaluated and found that the oral ingestion of a probiotic formulation LOBUN has significantly reduced the pathologic concentration of various marker molecules of CKD by a way of probably altering the composition of colon microbiota and generation of uremic toxins. Thus, the probiotic formulation LOBUN appears to be a promising candidate to serve as dietary supplement to maintain a natural metabolic and physiological renal mechanism. As the safety and efficacy of various probiotic organisms are substantiated by number of epidemiological studies and it is reasonable to conclude that this probiotic formulation LOBUN could be a promising drug candidate to be incorporated into clinical regimen in strict accordance with the guidelines of regulatory authorities by carrying out further studies.

\section{CONFLICT OF INTEREST}

Authors declared that there is no conflict of interests.

\section{REFERENCES}

ANDREW, S.L.; CORESH, J. Chronic kidney disease. Lancet, v.379, n.9811, p.165-180, 2012.

ANWAR, A.S.; NAIDU, M.U.R.; VIJAYKUMAR, K.; PRAYAG, A.; RATNAKAR, K.S. Effect of pentoxifilline on cyclosporine induced nephrotoxicity in rats. Indian. $J$. Experiment. Biol., v.38, n.4, p.347-352, 2000.

CHRISTIN, G.O.; KARASIK, K.K.; ASMAR, A. Uric acid as a marker of kidney disease: review of the current literature. Diseas. Markers, v.2015, ID382918, p.1-6, 2015. 
DANIEL, E.W.; TIGHIOUART, H.; ELSAYED, E.F.; GRIFFITH, J.L.; SALEM, D.N.; LEVEY, A.S. Uric acid and incident kidney disease in the community. J. Am. Soc. Nephrol., v.19, n.6, p.1204-1211, 2008.

EMMA, J.M.; CAMPBELL, K.L.; MUDGE, D.W.; BAUER, J.D. Achieving salt restriction in chronic kidney disease. Int. J. Nephrol., v.2012, ID720429, p.1-10, 2012.

FLORE, D.; COHEN, G.; SMET, R.D.; RODRIGUEZ, M.; JANKOWSKI, J.; VANHOLDER, R.; ARGILES, A. Normal and pathologic concentrations of uremic toxins. $J$. Am. Soc. Nephrol., v.23, n.7, p.1258-1270, 2012.

HILL, M.J. Role of gut bacteria in human toxicology and pharmacology. London: Taylor \& Francis Publishers, 1995. 286 p.

HODGKINSON A. Determination of oxalic acid in biological material. Clinic. Chem., v.16, n.7, p.547-57, 1970.

JINHWA, L. Use of antioxidants to prevent Cyclosporine A toxicity. Toxicol. Res., v.26, n.3, p.163-170, 2010.

KLAMMT, S.; WOJAK, H.J.; MITZNER, A.; KOBALL, S.; RYCHLY, J.; REISINGER, E.C.; MITZNER, S. Albuminbinding capacity $(\mathrm{ABiC})$ is reduced in patients with chronic kidney disease along with an accumulation of protein-bound uraemic toxins. Nephrol. Dialys. Transplant., v.27, n.6, p.2377-83, 2011.

KOPPE, L.; MAFRA, D.; FOUQUE, D. Probiotics and chronic kidney disease. Kidney. Int., v.88, n.5, p.958-66, 2015.

KOVESDY, C.P. Significance of hypo-and hypernatremia in chronic kidney disease. Nephrol. Dialys. Transplant, v.27, n.3, p.891-898, 2012 .

MARGARET, B.; GEHR, T. Chronic kidney disease: detection and evaluation. Am. Family Phys., v.84, n.10, p.1138-1148, 2011

MARIA, D.C.; PEREGO, R.; BELLIA, G. Cyclosporineassociated nephrotoxicity. J. Nephrol., v.3, n.3, p.168-180, 2013.
PARASURAMAN, S.; RAVEENDRAN, R.; KESAVAN, R. Blood sample collection in small laboratory animals. $J$. Pharmacol. Pharmacother., v.1, n.2, p.87-93, 2010.

PATEL, P.K.; PATEL,M.A.; SARALAI, M.G.; GANDHI,T.R. Antiurolithiatic effects of Solanum xanthocarpum fruit extract on ethylene-glycol-induced nephrolithiasis in rats. J. Young. Pharm., v.4, n.3, p.164-170, 2012.

PRADEEP KUMAR, C.H.; NARASIMHA REDDY, Y. Protective effect of Canavalia gladiate (sword bean) fruit extracts and its flavonoidal contents, against azathioprineinduced toxicity in hepatocytes of albino rats. Toxicol. Environ. Chem., v.98, n.3, p.1-8, 2014.

RAMESH, V.; GOVINDARAJAN, V.; OZA, N.; PARAMESWARAN, S.; DHANASEKARAN, B.P.; PRASHAD, K.V. Salivary creatinine estimation as an alternative to serumcreatinine in chronic kidney disease patients. Int. J. Nephrol., v.2014, ID742724, p.1-6, 2014.

RYU, E.S.; KIM, M.J.; SHIN, H.S.; JANG, Y.H.; CHOI, H.S.; JO, I.; JOHNSON, R.J.; KANG, D.H. Uric acid-induced phenotypic transition of renal tubular cells as a novel mechanism of chronic kidney disease. Am. J. Physiol. Renal. Physiol., v.304, n.5, p.F471-F480, 2013.

SHAH, A.P.; KALANTAR-ZADEH, K.; KOPPLE, J.D. Is there a role for ketoacid supplements in the management of CKD? Am. J. Kidney Diseas., v.65, n.5, p.659-673, 2015.

SHIGEHIKO, U.; BELLOMO, R.; GOLDSMITH, D. The meaning of the blood urea nitrogen/creatinine ratio in acute kidney injury. Clinic. Kidney J., v.5, p.187-191, 2012.

SUBHA PALANEESWARI, M.S.; NAGARAJAN, S.; MANJULA DEVI, A.J. Chronic kidney disease-effect of oxidative stress. Chinese. J. Biol., v.2014, n.216210, p.1-6, 2014.

ZEBA, K.; PANDEY, M. Role of kidney biomarkers of chronic kidney disease: an update. Saudi. J. Biol. Sci., v.21, n.4, p.294-299, 2014.

Received for publication on $13^{\text {rd }}$ March 2016 Accepted for publication on $24^{\text {th }}$ January 2017 